\title{
Measuring Service Quality with Servqual
}

Sajna, K. P.

Research Scholar, Department of Library \& Information Science

University of Calicut, Kerala - 673 635, India

sachumolmlisc@gmail.com

Mohamed Haneefa, K.

Assistant Professor, Department of Library \& Information Science

University of Calicut, Kerala - 673 635, India

dr.haneefa@gmail.com

ABSTRACT: This paper explores the concept of service quality and SERVQUAL as a tool for measuring service quality. It analyses the significance of measuring service quality in libraries and development of SERVQUAL scale for measuring service quality of libraries. It also pointed out the dimensions of SERVQUAL such as; Reliability, Tangibles, Responsiveness, Assurance and Empathy. The paper provides useful insight for service quality measurement in libraries.

Keywords: Service Quality, SERVQUAL, Quality Evaluation of Libraries, Library User Expectations, Library User Perceptions

Received: 14 August 2018, Revised 19 September 2018, Accepted 30 September 2018

DOI: $10.6025 / \mathrm{jit} / 2019 / 10 / 1 / 1-6$

(C) 2019 DLINE. All Rights Reserved

\section{Introduction}

Quality assumes an imperative part in everyday exercises of human life. Like commercial organisations, service organisations also have no exemption. The existence of every firm depends on how long they can satisfy their customers. The satisfaction of the customer is based on the quality of products and services provided by the firm. According to the business dictionary quality is "the measure of excellence or state of being free from defects". ISO 8402-1986 standard defines quality as "the totality of features and characteristics of a product or service that bears its ability to satisfy the stated or implied needs" (http://www.business dictionary.com/definition/ quality.html). A quality service is one which meets the needs and expectations of the users. It depends to a large extend upon how well they are delivered. Parasuraman, Zeithaml and Berry (1985) identified intangibility, heterogeneity and inseparability of production and consumption as the unique feature of service, therefore, they observed service quality as an elusive and abstract construct. Nitecki (1996) defined service quality in terms of "meeting or exceeding customer expectations, or as the difference between customer perceptions and expectations of service". Therefore, customer satisfaction is the ultimate factor behind service quality. 
The rapid changes in ICT have made libraries to face intense competition from other information service providers. In order to survive in the highly competitive environment, libraries need to provide quality information and services to its users. Ranganathan's fourth law of Library Science "save the time of the reader" emphasized the importance of service quality in libraries (Dash and Padhi, 2010). As far as a library is concerned, service quality implies that delivering the required service as expected by the user with no delay.

\section{Measuring Service Quality of Libraries}

Libraries go about as the spines of scholastic establishment. An efficient library system is unavoidable for the better execution of a scholarly organisation. All the libraries, like academic libraries, special libraries, public libraries etc are utilising different sources of fund to provide information and services to its users. Hence, they are responsible to the concerned authority for the effective utilisation of such funds. In order to provide quality services, libraries are attempted to assess the changing needs and expectations of the users. The information requirements of the users are also get affected by technological advancements. Therefore, libraries are applying techniques like user study, regular user interaction, feedback mechanism, etc to identify what users expect from them. Then the collections and services of the libraries are designed in a way as to meet such needs.

Service quality measurement has great significance in libraries. It helps to assess what users expect from a library and evaluate the perceptions of users about the services. Further, it identifies the feeble sections of the library and develops strategic plans for its improvement. User participation is essential in service quality evaluation. It will enhance healthy relationship between library staff and users. As far as a library is concerned, service quality measurement requires, a critical examination of all the sections of the library. It includes the collections, staff, technical process etc. Library needs to update its collections regularly to meet the changing needs of the users. In order to cope up with the technological changes, libraries are introducing many innovative services. The 'Ask Librarian' service facilitates the user to have direct interaction with the librarian as and when needed. Digital libraries, institutional repositories, online catalogue etc are the important services provided by library. Even though, the users may confront with troubles while accessing these services. Proper user orientation is essential for resolving it. As part of user orientation, libraries are conducting, seminar, workshop etc to make the users acquainted with the services of the library. Continuous training programs are imparted to the library staff for providing quality services to the users.

Since the service quality measurement gains much significance, the traditional methods are not capable of measuring it on the basis of user based approach. In this light, there have been number of tools developed for the purpose. Amidst, SERVQUAL emerged as an effective tool for service quality measurement.

\section{Literature Review}

There have been number of studies conducted on dimensions of SERVQUAL, its relative importance, application of SERVQUAL etc. which pave the path for the development of SERVQUAL as an effective tool for service quality measurement.

Asogwa et al (2014) applied the SERVQUAL instrument for service quality evaluation of academic libraries in developing countries. It was found that there exist significant difference between expectations and perceptions of the users and all the dimensions were negatively marked. The study also pointed out that "tangibles" as the most important dimensions and "empathy" as the least important one. Despite, a study conducted by Tan and Foo (1999) at Singapore statutory board library, observed that "Reliability" is ranked as the highest dimension followed by responsiveness and empathy as the lowest. Kaur and Diljith (2010) employed a modified SERVQUAL to evaluate the service quality of academic libraries in Malaysian University and observed that the library maintained service quality at above average level. Velnamby and Sivesan (2014) conducted factor analysis to identify the factors determining the service quality of libraries and established that convenient opening hours, current information, collection comprehensiveness and convenient access to collection as the important factors. Service quality assessment at KSCSTE libraries by applying SERVQUAL was conducted by Sajna and Haneefa (2017) reported that KSCSTE libraries lacks service quality.

\section{Development of SERVQUAL Instrument}

SERVQUAL is a quality measurement tool developed by Parasuraman, Zeithaml and Berry in 1985. Initially, it was designed to apply in commercial environment then further changes have been made in the subsequent years to be applicable in service organisations also. As service quality is defined as the gap between the expectations and perceptions of the customers,

\begin{tabular}{lllllll}
\hline 2 & Journal of Information Technology Review Volume & 10 & Number & 1 & February & 2019 \\
\hline
\end{tabular}


SERVQUAL is intended to measure the gap. When the gap is negative, it seems that the service quality is low and if the gap is positive it indicates that the service quality is high. The instrument has two parts; the expectation part and the perception part. The expectation part measures the expectations of the customer about the service whereas the perception part measures the experiences of the customer while consuming the service. There is a formula for measuring service quality.

Where $Q=$ Service Quality

$$
Q=P-E
$$

$P=$ Perceptions of the customer

$E=$ Expectations of the customer

The service quality measurement with SERVQUAL was relied on 10 dimensions. They are; tangibles, reliability, responsiveness, communication, credibility, security, competence, courtesy, understanding/knowing the customer and access. From these dimensions, 97 items were generated. For further refinement of the items, data was collected from a sample 200 customers of banking, credit card, appliance repair and maintenance, long distance telephone, securities brokerage and credit card. A 7 point Likert scale was used to mark the responses. The respondents were asked to indicate the expectations and perceptions. Then the coefficient alpha and item to total correlations for each of the dimension was calculated. On the basis of the results, items having low correlation were deleted to improve the alpha value. Then the item was reduced to 54 items. Factor analysis has done to ensure the dimensionality of the items. Due to the overlap in some dimensions, oblique rotation was done. As there are many items has high loading on more than one factor, it requires reassignment of the items by deleting some other items and restructuring of the dimensions. Again the coefficient alpha and item to total correlation was calculated. The process was repeated and results 34 items with 7 dimensions. By using the 34 items scale, data was collected from a sample of 200 customers of four firms; a bank, a credit card company, appliance repair and maintenance firm and a long distance telephone company. As there exist overlap between the dimensions, for further purification have done by deleting some more items and out of the seven dimensions, 4 dimensions were incorporated to form 2 dimensions. Thus resulted a 22 item scale with 5 dimensions. They are; tangibles, reliability, responsiveness, assurance and empathy (Parasuraman, Zeithaml and Berry 1988).

\section{Application of SERVQUAL in Libraries}

As the SERVQUAL was designed to apply in commercial environment, it needs to revised and modified to be applicable in libraries. During 1990's SERVQUAL have been started to apply in Library and Information Science. Danuta A Nitecki (1996) was first used the modified SERVQUAL in academic libraries for measuring service quality (Manjunatha and Shivalingaiah 2004). Peter Hernon, Ellen Altman, Danuta A Nitecki and many other experts have conducted numerous researches in the area of service quality measurement in libraries with SERVQUAL instrument and explored the concept deeply.

In SERVQUAL, quality measurement is based on customer responses. As in the case of libraries, users are the customers. Like any other firms, libraries also, customers or users are the ultimate judge of quality. Therefore, libraries are following a user based approach for improving quality. Through SERVQUAL assessment, libraries are in a position to identify the expectations and perceptions of the users and thereby assess the gap between them. It will help them to focus on those areas having the highest gap and provide more attention. SERVQUAL measures quality of different aspect of libraries on the basis of 5 dimensions. They are;

Reliability: It measures the ability of the library to provide the required services dependably and accurately. As a knowledge manufacturing centre, it is indispensable for the libraries to provide reliable information to the users. The quality of a library primarily depends on the accuracy and reliability of the information provided. Therefore, while measuring the service quality of the libraries, it is essential to measure whether the libraries provide accurate and reliable information as needed by the users.

Tangibles: The tangible dimension measures quality of those things which are tangibles in nature. It includes physical facilities of the library. As far as a library is concerned, physical facilities play vital role in quality enhancement. Users always needs comfortable atmosphere for their intellectual activities. Adequate space for reading, comfortable furniture, proper lighting and ventilation etc are inevitable for a reading environment. Hence, this dimension measures that, is there any problem with the physical facilities of the library.

Responsiveness: It measures the willingness of the library staff to provide the required services to the user as and when needed. 
Step 1: Define service equality as the discrepancy between the expectations and perceptions of customers about the services offered by a firm

Step 2: Identify 10 dimensions which constitutes service quality

Step 3: Generating 97 items under the 10 dimensions

I

Step 4: Collect data from a sample of 200 customers of 4 firms

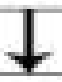

Step 5: Scale purification through the following iterative sequence

* Calculation of coefficient alpha and item to total correlations of each dimension

* Delete item having low correlation

* Reassign the items needed and restructure the dimensions

* Factor analysis

Step 6: Identification of 34 items based on 7 dimensions

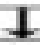

Step 7: Data collected from 200 samples of the same firm $\perp$

Step 8: Evaluation and scale purification by repeating the procedures in step 5

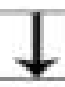

Step 9: Identification of 22 items under the five dimensions

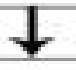

Step 10: Reliability measurement of the scale to ensure internal consistency

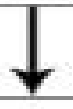

Step 11: Validity assessment of the scale

Figure 1. Steps in Developing a SERVQUAL Scale (Parasuraman, Zeithaml and Berry,1988) 
The users may not know the arrangements of the books in the library, they may demand the help of the staff to locate a particular book. Therefore, the staff should always be available to the users whenever needed and try to provide them best services as possible. It will develop a healthy relationship with them. Regular user interaction is the prerequisite for providing quality services to the users. Timeliness in delivery of the services avoids delay. Thus, the responsiveness dimension assessed the attitude of library staff towards the users.

Assurance: It measures the knowledge and courtesy of the library staff. The staff should have adequate knowledge to answer user queries. The users may be unaware about many of the services provided by the library, therefore, the staff should provide proper orientation to the users about such services. They should have the skill to handle the problems faced by the users when searching for information. In addition, they should have an approachable and welcoming attitude. It will enhance the confidence of the users. The assurance dimension evaluates the performance of library staff while measuring service quality of the libraries.

Empathy: It measures the caring and individualized attention provided to the user. There are different types of users with different character. They may behave indifferently. The library staff should have the emotional intelligence to deal with such incidents. This dimension observes how well the staffs respond to the specific needs of the individual user.

\section{Limitations of SERVQUAL}

SERVQUAL emerged as an effective tool for measuring service quality, even though there exist some limitations also. As the SERVQUAL is based on five dimensions, but the dimensions are not universally applicable. Therefore, changes have been made in the dimensions when applying in libraries. While measuring the service quality of university library in Bangladesh, Ahmed and Shoeb (2009) observed that only four dimensions such as affect of service (organizational), collection and access, library as a place and affect of service. Edward and Browne (1995) point out that the SERVQUAL dimensions lack technological features whereas in a study conducted by Abdul Majeed (2005), the dimensions are changed as physical facilities, library collection, library staff and technical process and library services.

Another major limitation is that, SERVQUAL measurement purely depended on expectations and perceptions of users. According to human nature, they always have high expectation and never get satisfied with anything. Due to this reason, perceptions remains as low on every statement. The expectations and perceptions are not stable, keep changing depends on the emotions of the user. Therefore, it may not be accurate and reliable, there may be chances of getting biased. It may affect the result (Ahmed and Shoeb 2009).

The items in the SERVQUAL instrument have high inter-correlations. Items are not properly attributed to corresponding dimensions. There is an overlap between some of the items. Besides these, the SEVQUAL instrument takes much time. The user is requested to respond on both the expectations and perceptions. As the users are in hurry with their own work, they may not respond genuinely to the statements. Furthermore, the expectations supposed to measure before the consumption of the service and perception measures only after the consumption. It was not possible due to practical difficulties. Therefore SERVQUAL instrument needs to be revised continuously with the corresponding changes in the technology and working environment. Nevertheless, with all these criticism, SERVQUAL still exist as an effective tool for service quality evaluation.

\section{Conclusion}

Provision of quality service is crucial for overcome the threatening position of libraries. As a service organisation, libraries service quality measurement has its own challenges. The study assessed the application of SERVQUAL as a tool for measuring service quality in libraries and emphasised the significance of measuring service quality. The SERVQUAL evaluation is based on five dimensions; they are; Reliability, Tangibles, Responsiveness, Assurance and Empathy. While measuring service quality, all these dimensions are equally important. Being an effective tool of service quality measurement, SERVQUAL possess some limitations also. The study also pointed out that a quality service should be based on user requirement. Library should develop a quality culture.

\section{References}

[1] Quality, (n.d.). http://www.business dictionary.com/definition/quality.html. accessed on 10/02.2018

[2] Parasuraman, A., Zeithaml, V. A., Berry, L. L. (1988). ServQUAL: a multiple item scale of measuring consumer perception of Journal of Information Technology Review Volume 10 Number 1 February 2019 
service quality. Journal of Retailing, 64 (1) 41-50.

[3] Nitecki, Danuta A. (1996). Changing the Concept and Measure of Service Quality in Academic Libraries. Journal of Academic Librarianship, 22 (3) 181-190. doi: 10.1016/S0099-1333(96)90056-7.

[4] Dash, N. K., Padhi, P. (2010). Quality Assessment of Libraries. DESIDOC Journal of Library \& Information Technology, 30 (6) $12-23$.

[5] Asogwa, Brendan, E., Asadu, Boniface, U., Ezema, Jonas, U., Ugwu, Cyprian, I., Ugwuanyi, Ferdinand, C. (2014). Use of ServQUAL in the evaluation of service quality of academic libraries in developing countries. Library Philosophy and Practice (e-journal). (2014). http://digitalcommons.unl.edu/libphilprac/1146)

[6] Tan, Pey Lin., Foo, Schubert. (1999). Service quality assessment: a case study of a Singapore statutory board library. Singapore Journal of Library and Information Management, 28, 1 - 23.

[7] Kiran, K., Diljit, S. (2012). Modeling web-based library service quality. Library and Information Science Research, 34, 184196.

[8] Velnamby, T., Sivesan, S. (2013). Factor Analysis of Service Quality in University Libraries in Sri Lanka - An Application of Servqual Model. Industrial Engineering Letters, 3(5) (2013).

[9] Sajna, K. P., Haneefa, K. M. (2017). Service Quality of Research Institute Libraries of Kerala State Council for Science, Technology and Environment. In: Two Day National Level Conference on Professionalism in Library and Information Services for User Empowerment: Opportunities and Challenges, 27-28 April 2017, Mangalore. 2017. p. 372-380.

[10] Manjunatha, K., Shivalingalah, D. (2004). Customer's perception of service quality in libraries. Annals of Library and Information Studies, 51 (4) 145-151.

[11] Ahmed, Zabed, S. M., Shoeb, Zahid Hossain. (2009). Measuring service quality of a public university library in Bangladesh using SERVQUAL. Performance Measurement and Metrics, 10 (1) 17-32.

[12] Edwards, Susan., Browne, Mairkad. (1995). Quality in Information Services: Do Users and Librarians Differ in Their Expectations?. Library \& Information Science Research, 17, 163-182.

[13] Majeed, Abdul., K. C. (2005). College Library Services: A Quality assessment. University of Calicut. 2005. PhD Thesis. 112. 